\title{
Psychospołeczne skutki redukcji zatrudnienia i przeciwdziałanie na przykładzie firmy inwestycyjnej
}

\author{
Autor: Lech Miklaszewski
}

\begin{abstract}
Abstrakt
Artykuł przedstawia problematykę psychospołecznych skutków derekrutacji dotykających tych, którzy uchronili się przed zwolnieniem. W tym kontekście celem artykułu jest identyfikacja tych skutków oraz sposobów przeciwdziałania destrukcyjnym efektom derekrutacji. Powyższa problematyka została zilustrowana studium przypadku firmy inwestycyjnej wspartego wynikami badań ankietowych. Rezultaty badań wskazały, że w przypadku badanej firmy redukcja zatrudnienia nie była odpowiednio przygotowana, a wśród tych pracowników, którzy zachowali posady, spowodowała zmniejszenie poczucia stabilności zatrudnienia, wywołała wysoki poziom stresu, zmniejszyła lojalność, zaangażowanie i zaufanie do kierownictwa, wywołała obawy dotyczące większego obciążenia pracą, a decyzje o zwolnieniu potraktowano jako niesprawiedliwe i nieuzasadnione. Wraz z upływem czasu pejoratywne odczucia tych, którzy pozostali w firmie, nasiliły się. Na tym tle przedstawiono również wskazówki dotyczące konstruktywnych zachowań i przedsięwzięć eliminujących błędy i łagodzących skutki derekrutacji.
\end{abstract}

Słowa kluczowe: redukcja zatrudnienia, konsekwencje redukcji, choroba przetrwania redukcji

JEL: J21
Historia: otrzymano 2015-06-09, poprawiono 2015-11-27, zaakceptowano 2015-11-30

\section{Wstęp}

Współczesne przedsiębiorstwa działają pod olbrzymią presją kosztów. Niestety, obserwując praktykę ich „racjonalizowania”, można zauważyć, że wiele z nich uznaje redukcję zatrudnienia za główny, a często jedyny sposób podniesienia efektywności. Być może w niektórych przypadkach taka decyzja jest uzasadniona i słuszna, ale przedsiębiorcy, wdrażając ją w życie, popełniają kolejny błąd, skupiając swoją uwagę na kosztach i innych konsekwencjach dotyczących zwalnianych pracowników, lekceważąc lub w ogóle nie dostrzegając społecznych skutków derekrutacji dotykających tych, którzy uchronili się przed zwolnieniem. Są one na tyle istotne, że ich 
nieuwzględnienie $w$ rachunku korzyści i kosztów całej operacji redukcji personelu może skończyć się katastrofą. Nie bez powodu psychospołeczne koszty tego procesu nazywane są „parszywą dwunastką" a obejmują: centralizację decyzji, kryzysową mentalność, utratę innowacyjności, opór wobec zmian, spadek morale, upolitycznienie klimatu społecznego, zanik priorytetów, utratę zaufania, narastanie konfliktów, zakłócenia w komunikacji wewnętrznej, deficyt w pracy zespołowej, anemię przywództwa. Inni autorzy stan psychospołeczny tych, którzy po redukcji pozostali w pracy, nazywają chorobą przetrwania redukcji. „Jej syndromem są m.in.: poczucie niepewności pracy; percepcja niesprawiedliwości; depresja; stres wynikający ze zwiększonego obciążenia pracą; lęk przed zmianą; spadek lojalności i zaangażowania; zmniejszenie skłonności do podejmowania ryzyka; spadek motywacji; niechęć do robienia czegokolwiek poza wymaganym minimum; poczucie, że jest się niedoinformowanym; utrata zaufania do kierownictwa wyższego szczebla" (Robbins 2003: 157). Lekceważenie tych objawów to poważny błąd, którego skutki, szczególnie w sferze zarządzania zasobami ludzkimi, są nie do przecenienia.

W tym kontekście celem artykułu jest identyfikacja psychospołecznych skutków redukcji zatrudnienia oraz sposobów przeciwdziałania destrukcyjnym skutkom derekrutacji wśród tych pracowników, którzy zachowali swoje posady, zilustrowana studium przypadku firmy inwestycyjnej.

Podstawą realizacji tak określonego celu były badania ankietowe, wywiady oraz konstatacje wynikające $z$ obserwacji uczestniczącej (autor referatu jest długoletnim pracownikiem badanej firmy inwestycyjnej). Wyniki badań dotyczą przykładowej firmy i jako takie nie pretendują do formułowania wniosków ogólnych.

\section{Redukcja zatrudnienia, jej konsekwencje psychospołeczne oraz narzędzia ograniczania negatywnych skutków derekrutacji - aspekt teoretyczny}

Kryzys gospodarczy to czas sprzyjający decyzjom racjonalizacji kosztów. Niestety zbyt często wybiera się najprostsze wyjście, najczęściej pozbawione głębszych refleksji, choć budzące silne emocje - redukcję personelu. W ten sposób racjonalizację kosztów utożsamia się z ich cięciem, co jest ewidentnym błędem. Biorąc pod uwagę, że redukcja zatrudnienia to przeciwstawienie interesów pracodawcy i pracowników, w grę wchodzą również różne argumenty merytoryczne i etyczne uzasadniające stanowiska stron, choć oczywiście pozycja zwalnianych pracowników jest $w$ tej konfrontacji o wiele słabsza. Można jednak stwierdzić, że „zwalnianie z pracy jest etyczne, gdy właściwą osobę usuwa się $z$ właściwych powodów i we właściwy sposób" (Stemberg 1998: 179). Rzadko kiedy mówi się jednak o pozycji i kondycji tych, którzy uchronili się przed zwolnieniem. Menedżerowie często lekceważą wpływ, jaki zmniejszenie zatrudnienia wywiera na tych, którzy je przetrwali, choć coraz więcej wyników badań świadczy o tym, że redukcje poważnie wpływają także na tych pracowników, którzy zachowali pracę. „Kierownicy, którzy lekceważą te zjawiska i nie zajmą się nimi, zapewne będą mieli do czynienia ze znacznym spadkiem efektywności organizacji" (Robbins 2003: 157). Wobec tych, którzy pozostają, potrzebny jest również akt przyzwoitości. „Chociaż pracowników zwalnia się z pracy, to nie tak fatwo wymazać ich wspomnienia. Poczucie winy tych, którzy zostali, jest problemem jak najbardziej realnym, z którym można sobie poradzić, ale tylko pod warunkiem, że uznamy, iż taki problem istnieje. (...) Ignorowanie faktu, że redukcja 
zatrudnienia dotknęła także pracowników, którzy pozostali w firmie, może mieć bardzo negatywny i długotrwały wpływ na wyniki i na morale personelu" (Harrisom 2008: 185). Oczywiście pracownicy, którzy pozostali, bardzo chcą usłyszeć, że proces redukcji zatrudnienia został zakończony i że ich stanowiska nie są zagrożone. Jednak liderzy powinni zwalczyć pokusę powiedzenia, że to już koniec, nie będzie więcej zwolnień. Powinni mówić prawdę, nawet wtedy, kiedy jest ona przeciwieństwem tego, co pozostali $\mathrm{w}$ firmie pracownicy pragnęliby usłyszeć. Przecież proces redukcji nigdy nie ma końca, a obietnica długoterminowego zatrudnienia, szczególnie w obecnych, turbulentnych warunkach, jest zwykłą iluzją ( Harrisom 2008: 186). W tym kontekście aktem przyzwoitości jest prawda. Pokrętne i bezduszne postępowanie kierownictwa $w$ tak trudnym momencie, jak redukcje zatrudnienia, przynosi niepowetowane straty. Dotyczy to w szczególności warunków panujących na rynku, na którym dziata badana firma inwestycyjna. Rynek kapitałowy jest bowiem środowiskiem na tyle zmiennym i wymagającym, że bezrefleksyjne trwonienie kapitału ludzkiego, łamanie lojalności personelu, wystawianie zaufania na próbę może skończyć się porażką $\mathrm{w}$ wymiarze komercyjnym.

„Wielu menedżerów wierzy, że jeśli po redukcjach mniej się o nich mówi, tym lepiej. (...) W rzeczywistości jest tak, że pracownicy, którzy przetrwali, będą mówić o tym, co się zdarzyło, niezależnie od tego, czy się to podoba kierownictwu. Im usilniej przedsiębiorstwo próbuje tłumić te dyskusje i działa tak, jakby nic się nie stało, tym bardziej wywrotowa staje się dyskusja" (Downs 2007: 25). Powrót do normy po redukcjach odbywa się znacznie szybciej, jeśli menedżerom i pracownikom pozwala się swobodnie wyrażać opinie o tym, co się wydarzyło, pozwala to również na odbudowę więzi wśród tych, którzy przetrwali redukcję (Downs 2007: 25). Niestety, często powrót do normy to droga przez mękę, szczególnie wówczas gdy skutki redukcji dotkliwie dotykają nie tylko pozostały po redukcji personel, ale również istotne sfery zarządzania, jak chociażby zarządzanie zasobami ludzkimi, a w rezultacie zarządzanie biznesem. Stephen P. Robbins twierdzi, że syndromem tej sytuacji są (Robbins 2003: 157):

- poczucie niepewności pracy - pracownicy, którzy pozostali, obserwując problemy kolegów, którzy stracili pracę z przyczyn od nich niezależnych, tracą również poczucie własnej wartości i stabilności zatrudnienia;

- percepcja niesprawiedliwości brak sprawiedliwości dystrybutywnej i proceduralnej w procesie podejmowania decyzji o redukcji, której motywem jest przecież ograniczenie kosztów, a nie selekcja kwalitatywna kandydatów do zwolnienia, rodzi poczucie niesprawiedliwości;

- depresja - „nawet w najlepiej przeprowadzonych redukcjach ci, którzy je przetrwali, czują, że popełniono na nich gwałt. Zanim zdołają się z tego otrząsnąć, muszą mieć możliwość wyzwolenia swoich uczuć" (Robbins 2003: 158). Jeżeli im się to uniemożliwia i tłumią swoje emocje, najczęściej popadają w stan przygnębienia, który rodzi depresję;

- stres wynikający ze zwiększonego obciążenia pracą - redukcja zatrudnienia przekształca przedsiębiorstwo, a w nowej jego organizacji niejednokrotnie oznacza to konieczność wykonywania przez "ocalałych" obowiązków, które do tej pory były realizowane $\mathrm{w}$ większym zespole. $\mathrm{W}$ tych okolicznościach ludzie niepokoją się, że nie będą potrafili wykonać nowych zadań albo stosować nowych 
metod zgodnie z wcześniejszymi normami, zwłaszcza gdy płaca jest ściśle zależna od wydajności;

- lęk przed zmianą - jeżeli redukcję zatrudnienia potraktujemy jako zmianę lub jej skutek, musimy spodziewać się oporu, bo ludzie zawsze przeciwstawiają się zmianom. Dezaprobata, sprzeciw wobec zmiany polegającej na redukcji zatrudnienia, a więc zmiany najbardziej dotkliwej dla ludzi, kształtuje odpowiednio i aurę, i emocje, kierowane później przeciw wszelkim zmianom,

- spadek lojalności i zaangażowania - obserwując krzywdę zwalnianych kolegów i pojmując ją w kategoriach niesprawiedliwości, trudno spodziewać się wierności i rzetelności w stosunkach z pracodawcą - poziom lojalności spada. Wpływa to również destrukcyjnie na zaangażowanie pojmowane jako intelektualne i emocjonalne oddanie organizacji lub jako wielkość wysiłku włożonego w pracę przez pracownika (Juchnowicz 2010: 35);

- zmniejszenie skłonności do podejmowania ryzyka - ten syndrom ma bezpośredni związek z poprzednim. W warunkach braku zaangażowania podejmowanie ryzyka jest nieracjonalne i nieuzasadnione;

- spadek motywacji - motywacja w tym kontekście jest kategorią syntetyczną, wypadkową wszystkich cech omawianej sytuacji. Gdy występuje brak pewności pracy, poczucia sprawiedliwego traktowania, gdy dotykają nas stany depresyjne, gdy stres uderza silniej niż zwykle, gdy łamie się lojalność i nie widzimy uzasadnienia angażowania się w organizację, motywacja nie tylko spada, ale w skrajnych przypadkach zanika całkowicie popadamy w emocjonalny marazm i apatię;

- niechęć do robienia czegokolwiek poza wymaganym minimum
- powyższa implikacja, kończąca się spadkiem motywacji, skutkuje minimalizmem i samoograniczeniem w zakresie wykonywania obowiązków;

- poczucie, że jest się niedoinformowanym - jeżeli pracodawca nie rozmawia z pracownikami, szczególnie w temacie tak wrażliwych kwestii, jak redukcja zatrudnienia, więź komunikacyjna zanika. Pracownicy zaskakiwani przez pracodawcę odczuwają niedobór informacji, szczególnie tych, które dotyczą motywacji i zamiarów pracodawcy;

- utrata zaufania do kierownictwa wyższego szczebla - jeżeli potraktujemy zaufanie jako zakład podejmowany na temat niepewnych, przyszłych działań innych ludzi (Sztompka 2007: 69-70), to możemy z dużą pewnością przewidywać, że w opisanych warunkach kierownictwo ten zakład przegra.

Inaczej ten syndrom przedstawia $A$. Pocztowski (Pocztowski 2008: 172):

- centralizacja - podejmowanie decyzji koncentruje się na najwyższym szczeblu zarządzania, a menedżerowie niższego szczebla unikają przyjmowania na siebie jakiejkolwiek odpowiedzialności;

- kryzysowa mentalność - zaniedbywane jest planowanie strategiczne, a cały wysiłek koncentruje się na sprawach bieżących, często traktowanych jako wydarzenia kryzysowe;

- utrata innowacyjności - wszelkie kreatywne inicjatywy ulegają zablokowaniu, nikt nie podejmuje ryzyka, zanika tolerancja dla błędów i niepowodzeń;

- opór wobec zmian - zmiana jest utożsamiana z zagrożeniem, unika się zmian, a akceptowane są jedynie działania przebiegające według utartych schematów;

- pogorszenie stosunków interpersonalnych - panuje atmosfera niechęci, izolacji i podejrzliwości; 
- upolitycznienie - nasila się walka o władzę pomiędzy grupami interesów;

- zanik priorytetów - konflikty bywają ograniczane poprzez dokonywanie "cięć" w poprzek całej organizacji, bez uwzględnienia konstruktywnych priorytetów determinujących efektywne działania przedsiębiorstwa;

- utrata zaufania - brak zaufania staje się powszechny i obejmuje wszystkie szczeble hierarchii organizacyjnej;

- narastanie konfliktów - intensyfikują się konflikty o podział wpływów i korzyści;

- ograniczona komunikacja - brak zaufania zmniejsza do minimum wymianę informacji między pracownikami. Informacje przekazywane przełożonym idealizuje się.;

- zanik pracy zespołowej - partykularne interesy i brak spójności uniemożliwiają współdziałanie;

- osłabienie przywództwa - menedżerowie przestają spełniać rolę przywódców, a ich działania ograniczają się do funkcji administracyjnych.

Wymienione wyżej psychospołeczne skutki zwolnień mogą mieć inny charakter w przedsiębiorstwach o mniejszej liczbie zatrudnionych (przypadek badanej firmy), gdzie wzajemne relacje są mniej sformalizowane, czy wręcz towarzyskie. Dezintegracja takiej grupy skutkuje przeważnie bardziej intensywnymi emocjami i większą traumą. Negatywnych skutków redukcji personelu dla osób pozostających w firmie, jak również dla dalszego jej funkcjonowania, nie sposób uniknąć. Można je jednak próbować minimalizować lub działać profilaktycznie. Sprzyja temu na przykład (Sidor-Rządkowska 2010: 76):

- prowadzenie otwartej polityki komunikacyjnej - redukcja zatrudnienia to typowa sytuacja kryzysowa, a z nią zawsze wiąże się atmosfera niepewności i niedomówień. Aby przełamać atmosferę skrytości i złej passy, wiadomości powinny być przekazywane za pomocą jasnych, jednoznacznych sformułowań, tak aby ludzie zrozumieli sens restrukturyzacji i swoją rolę $w$ tym procesie;

- opracowanie jednoznacznych kryteriów wyboru osób przeznaczonych do redukcji - ta kwestia budzi zawsze najwięcej emocji, niemniej kryteria są konieczne $\mathrm{i}$ to $\mathrm{w}$ dodatku sprawiedliwe. Często budowa tych kryteriów ukierunkowana jest przede wszystkim na poprawę efektywności jednostki, jednak nieliczenie się $z$ preferencjami personelu dotyczącymi tego, kto powinien zostać zwolniony, powoduje, że płacimy utratą lojalności osób pozostających w organizacji.

- niezwłoczne poinformowanie wszystkich pracowników o podjętych decyzjach - „Przekonanie, że osoba zagrożona zwolnieniem pracuje lepiej, jest szkodliwym mitem. Przedłużająca się niepewność dotycząca stanowisk pracy może drastycznie obniżyć efektywność funkcjonowania firmy" (Sidor-Rządkowska 2010: 76). Oczekiwanie przez personel na najgorsze jest dysfunkcjonalne i zakłóca proces pracy, stąd podjęte decyzje powinny być natychmiast komunikowane;

- dbałość o odpowiednią formę rozstania z pracownikami objętymi redukcją zatrudnienia - wszelkie objawy braku szacunku i lekceważenia odchodzących z firmy pozostaną na długo nie tylko w pamięci osób bezpośrednio dotkniętych tego typu zachowaniami, ale także w pamięci współpracowników, którzy pozostają;

- zerwanie z przekonaniem, że dla pozostających w przedsiębiorstwie sam fakt, iż nadal mają pracę, jest wystarczającym środkiem motywującym do największych nawet 
wysiłków - pracownicy, którzy uchronili się przed redukcją, zbyt często pozostają osamotnieni wobec zwiększonego zakresu obowiązków. Otwartość na problemy wynikające z konieczności funkcjonowania w nowych warunkach powinna pomóc przezwyciężyć te trudności.

S.P. Robbins preferuje etapowe podejście do problemu choroby przetrwania redukcji (Robbins 2003: 158-159):

Etap 1. Poprawne zaprojektowanie procesu - cechy takiego procesu to: jasne i szybkie cięcia; dostarczanie wszystkim zatrudnionym pełnej informacji; dostatecznie wczesne uprzedzenie osób wyznaczonych do redukcji; bycie emocjonalnie uczciwym i otwartym w komunikacji; otwarte wyjaśnianie decyzji i podejmowanie ich z uwzględnieniem kategorii sprawiedliwości; jeżeli to możliwe, pozwolenie pracownikom na uczestniczenie $w$ podejmowaniu decyzji.

Etap 2. Pozwolenie pracownikom na okazywanie żalu, tak aby mogli sobie poradzić z tłumionymi uczuciami i emocjami - redukcje zawsze budzą złe uczucia, natomiast ich wyzwolenie pozwala przetrwać, pozwala na odblokowanie. Ci, co pozostali, „muszą przejść przez proces żałoby podobny do tego, przez jaki przechodzi się po śmierci członka rodziny" (Robbins 2003: 158) i trzeba im to umożliwić.

Etap 3. Przerwanie łańcucha zależności organizacyjnej - na tym etapie dąży się do udzielenia tym, którzy przetrwali redukcję, pomocy w odzyskaniu ich poczucia sprawowania kontroli nad pracą i wiary w siebie - takie postawy zapobiegają wystąpieniu tej choroby przez przeniesienie ludzi z zależności organizacyjnej do samodzielnej kariery, z lojalności wobec pracodawcy do lojalności wobec własnej kariery.

Etap 4. Przekształcenie systemu organizacji tak, aby ograniczyć procesy prowadzące do zależności - w tym etapie dąży się do pomagania ludziom w nabyciu odporności na chorobę przetrwania redukcji, eliminując w organizacji praktyki paternalistyczne i nadopiekuńczość.

Choć może się to wydać cyniczne, wszystkie te działania służą przede wszystkim minimalizowaniu negatywnych skutków redukcji zatrudnienia nie tyle dla pozostających pracowników, ile dla dalszego, efektywnego funkcjonowania przedsiębiorstwa.

\section{Analiza skutków redukcji zatrudnienia w firmie inwestycyjnej - studium przypadku}

Badania dotyczące psychospołecznych skutków redukcji zatrudnienia przeprowadzono w firmie inwestycyjnej, diagnozując je wśród pozostałych po redukcji, w dwóch etapach: bezpośrednio po zwolnieniu części personelu i dwa miesiące później, licząc, że po upływie tego czasu nastąpi racjonalizacja postaw.

Firma inwestycyjna rozpoczęła działalność maklerską w roku 2006, na bardzo konkurencyjnym rynku. Jej działalność zaprojektowano tak, by mogła się wpisać w aktualne potrzeby rynku bez podejmowania destrukcyjnej walki konkurencyjnej; jednocześnie kreowano te potrzeby.

W rezultacie firma świadczyła dwa rodzaje usług: zarządzanie aktywami klientów oraz oferowanie instrumentów finansowych. W obu dziedzinach osiągnięto spektakularne sukcesy, choć kryzys doprowadził do rezygnacji i stopniowego wygaszenia nierentownej usługi zarządzania aktywami klientów. Do znaczących osiągnięć firmy należy zaliczyć: stworzenie biznesowej grupy kapitałowej, debiut i notowania na giełdzie (sierpień 2007 r. - NewConnect; lipiec 2011 r. - rynek główny GPW) oraz zgromadzenie kapitału, z dwóch emisji akcji na rynku giełdowym, przekraczającego wielokrotnie kapitał akcyjny. Wprawdzie począwszy od roku 2008, a więc $w$ latach nasilenia się zjawisk 
kryzysowych, firma notowała stratę, ale wcześniej wypracowany zadatek (emisja, zysk) pozwoliły na bezpieczne przetrwanie i, mimo wszystko, na dodatni wynik skonsolidowany całej grupy kapitałowej. Ten kierunek jest nadal kontynuowany, choć firma, funkcjonując na chimerycznym pod względem koniunktury rynku kapitałowym, wciąż boryka się z kryzysami. Niestety, jeden z nich skłonił zarząd firmy do podjęcia decyzji o redukcji zatrudnienia, co stato się z kolei podstawą przeprowadzonych badań.

W ramach grupy kapitałowej zbudowanej przez firmę prowadzona jest działalność transakcyjna i inwestycyjna. Ta pierwsza koncentruje się $w$ samej firmie inwestycyjnej oraz w spółce córce pełniącej funkcję autoryzowanego doradcy, natomiast ramieniem inwestycyjnym grupy jest spółka o charakterze holdingowym, posiadająca udziały w wehikułach inwestycyjnych o profilach inwestycyjnych związanych z wierzytelnościami i private equity.

Obecnie więc skonsolidowana firma specjalizuje się w usługach bankowości inwestycyjnej (emisje akcji - rynek główny, rynek NewConnect; emisje obligacji - rynek Catalyst; doradztwo przy fuzjach i przejęciach) oraz w zarządzaniu inwestycjami (inwestycje private equity; inwestycje w sektor wierzytelności).

W ciągu siedmiu lat działalności firma stała się jednym z liderów w obsłudze małych i średnich spółek w Polsce, realizując ponad 60 transakcji (w tym ponad 40 debiutów giełdowych) i pozyskując dla swoich klientów blisko 500 $\mathrm{mln}$ zł.

Firma w zakresie kadry łączy doświadczenie z młodością, deklarując, że ludzie to jej główny atut i podstawa rozwoju. Personel firmy stanowi zespół młodych, ambitnych i doskonale wykształconych profesjonalistów rynku kapitałowego, posiadających odpowiednie kwalifikacje zawodowe i bogate doświadczenie praktyczne.
Ponadto, firma jest przedsiębiorstwem rodzinnym - na 15 obecnie zatrudnionych pracowników aż 5 to członkowie dwóch rodzin. Obie rodziny mają swoich przedstawicieli w zarządzie spółki oraz na wyższych stanowiskach menedżerskich. Co więcej, przedstawiciele tych rodzin pełnią funkcje kierownicze w pozostałych spółkach grupy kapitałowej. Osoby te są również pomysłodawcami, organizatorami i właścicielami biznesu, ale także głównymi kreatorami autorskiej kultury organizacyjnej, która z uprzednio kultywowanej kultury klanu przekształciła się obecnie w bardziej zdecydowaną i drapieżną kulturę rynku.

W związku z tym, że grupa kapitałowa utworzona przez firmę jest strukturą skomplikowaną i wymagającą profesjonalnego zarządu, a de facto dysponuje ograniczonym personelem, we wszystkich spółkach wchodzących w skład grupy znajduje zastosowanie unia personalna w ramach zarządów oraz zatrudnienie krzyżowe wśród pracowników. Wynika stąd, że omawiana redukcja zatrudnienia dotknęła praktycznie wszystkie podmioty stanowiące grupe. W przeddzień redukcji grupa zatrudniała 20 pracowników, w tym 4 członków zarządu firmy inwestycyjnej. Po zwolnieniu 6 pracowników stan zatrudnienia zmniejszył się do 14 osób, w związku z tym, pomijając członków zarządu, grupa respondentów uczestniczących w badaniu liczyła 8 osób (jedna osoba przebywała na urlopie macierzyńskim, a kolejna na zwolnieniu lekarskim). Wszyscy badani byli związani z przedmiotową firmą inwestycyjną, różnymi rodzajami umów, pełniąc jednocześnie inne funkcje w pozostałych spółkach grupy. Związki te miały charakter nie tylko formalny, ale również pozaformalny - towarzyski, wręcz przyjacielski (wszystkie spółki grupy mają swoją siedzibę w tych samych pomieszczeniach), stąd poczucie przynależności czy tożsamości dotyczy raczej całej grupy niż tylko firmy 
inwestycyjnej (Informacje i dane zgromadzone podczas zatrudnienia $\mathrm{w}$ badanej firmie).

Zwolnienia, które miały miejsce w firmie inwestycyjnej, były całkowitym zaskoczeniem dla zatrudnionych. Osoby przeznaczone do zwolnienia otrzymywały zaproszenie do sali konferencyjnej, gdzie w obecności zarządu firmy była im komunikowana decyzja i jej uzasadnienie. Uzasadnienie w każdym przypadku było takie samo: brak zleceń wynikający z dekoniunktury na rynku kapitałowym i związana z tym konieczność redukcji kosztów. Pomimo tego, że uzasadnienie przeprowadzenia całej operacji było klarowne, to jednak kryteria indywidualne, odnoszące się do poszczególnych osób, nie były w ogóle artykułowane. Fakt ten wzbudzał uczucie braku sprawiedliwości i obiektywizmu, bowiem zwolnieniu podlegali zarówno, wydawałoby się, kluczowi pracownicy, z dużym doświadczeniem i wiedzą, jak i osoby mniej doświadczone i realizujące zadania mniejszej wagi. Klucz do zwolnień pozostał do tej pory tajemnicą.

Cięcie było błyskawiczne, ale pozbawione jakichkolwiek kroków wstępnych, przygotowujących pracowników do tego traumatycznego przeżycia, zarówno tych zwalnianych, jak i tych, którzy pozostali. Zdecydowanie pracodawcy podkreślała również praktyka natychmiastowej blokady komputerów osób odchodzących oraz zwolnienie od obowiązku świadczenia pracy w okresie wypowiedzenia. Rzeczą charakterystyczną była również bezproblemowa wypłata należnych odpraw oraz zgoda na rozwiązanie z pracownikiem umowy o zakazie konkurencji, co zapewniło wielu pracownikom komfortowe warunki poszukiwania pracy. Po realizacji zwolnień nie było żadnego spotkania z tymi, którzy pozostali, nie dochodziło również do rozmów indywidualnych z tymi osobami. Uznano widocznie, że sytuacja jest transparentna i nie wymaga jakichkolwiek zabiegów wobec tych, którzy uchronili się od zwolnienia (Informacje uzyskane podczas wywiadów bezpośrednich z pracownikami badanej firmy).

Reasumując, popełniono wiele błędów, choć prawdopodobnie nieświadomych. Do podstawowych można zaliczyć brak komunikacji i błędy w komunikacji, brak klarownych kryteriów kwalifikacji do zwolnienia, przeprowadzenie operacji redukcji bez przygotowania i bez prób włączenia pracowników w proces zwalniania, pozostawienie tych, którzy uchronili się od zwolnienia, samym sobie.

Z drugiej strony przeprowadzona redukcja miała swoje zalety. Tutaj należy wspomnieć o szybkiej, wręcz natychmiastowej realizacji przedsięwzięcia redukcji zatrudnienia, co uchroniło wszystkich jego uczestników od niepewności i spekulacji, kto zostanie zwolniony i kiedy do tego dojdzie oraz o niekonfrontacyjnych zachowaniach pracodawcy, który dążył do bezkonfliktowego rozwiązania problemu, stwarzając zwalnianym szansę szybkiego znalezienia przez nich nowej pracy. Meritum przeprowadzonych badań dotyczyło reakcji i postaw tych, którzy pozostali w firmie, którzy uchronili się przed zwolnieniem. Badania przeprowadzono w dwóch turach. Pierwszy etap miał miejsce następnego dnia po zwolnieniu, natomiast drugi po dwóch miesiącach od tego wydarzenia. Chodziło o stwierdzenie, czy emocjonalne reakcje pracowników dzień po zwolnieniach zostały dwa miesiące później zweryfikowane przez czas i refleksję. Główny trzon metodologiczny badań stanowiła anonimowa ankieta składająca się z 11 pytań zamkniętych.

Pierwsze pytanie dotyczyło określenia, czy redukcja zatrudnienia była dla respondentów zaskoczeniem.

Wszystkich ośmiu respondentów odpowiedziało twierdząco.

Okazuje się, że całkowicie pominięto okres przygotowawczy, który powinien 
zostać poświęcony wyjaśnianiu przyczyn planowanej redukcji, określeniu charakteru rozstania, czasu, w jakim będzie się odbywał, ile osób obejmie oraz sprecyzowaniu form wsparcia dla zwalnianych, ale i dla tych, którzy pozostają, ewentualnemu szkoleniu menedżerów, którzy będą musieli przeprowadzić kluczowe rozmowy, tak aby wręczanie wypowiedzeń odbyło się z zachowaniem szacunku i było okazją do udzielenia wszelkiej potrzebnej w tym momencie informacji i wsparcia (Sowa 2014, www.centrumrekrutacyjne.pl). To wszystko jest ważne, ponieważ "ocaleńcy" będą pilnie obserwowali i charakter rozstania, i sposób, w jaki potraktowani zostaną zwolnieni koledzy. Wnioski, które wyciągną, będą rzutowały na atmosferę w pracy już po zakończeniu tego procesu. Oczywiście zwalniać trzeba szybko. „Przedłużający się, wielomiesięczny okres niepewności, czyli sytuacja, w której firmowy korytarz huczy od plotek o zwolnieniach, wpływa na drastyczny spadek motywacji i efektywności pracy. Najlepiej stosować zasadę: decyzja dziś - realizacja za miesiąc. Ale też nie można pracownika zaskakiwać" (Sowa 2014, www.centrumrekrutacyjne.pl). Niestety w analizowanym przypadku zaskoczenie było pełne.

Drugie pytanie dotyczyło określenia, czy kierownictwo firmy dostarczyło wszystkim zatrudnionym pełną informację o przyczynach i kryteriach redukcji zatrudnienia.

Odpowiedzi były podzielone: czterech pracowników odpowiedziało, że tak, a kolejnych czterech, że nie.

Takie zróżnicowanie wypowiedzi wynikało prawdopodobnie ze znajomości, wśród wszystkich respondentów, sytuacji ekonomicznej firmy (jest to spółka publiczna i dostęp do informacji na jej temat jest otwarty) i jej potrzeb w zakresie oszczędności i racjonalności finansowej, a jednocześnie z niefortunnego sformułowania pytania, które niezbyt ostro rozdzielało pod względem semantycznym różne przecież kategorie przyczyn i kryteriów. Z jednej strony ogólna przesłanka podjęcia decyzji o redukcji zatrudnienia była dla wszystkich oczywista: ograniczenie kosztów, z drugiej zaś różnie rozkładali oni akcenty, przypisując odmienne znaczenie poszczególnym kategoriom - jedna grupa uznawała redukcję kosztów jako przesłankę syntetyczną obejmującą również kryteria personalne zwolnienia z pracy, druga zaś, akceptując przesłankę ogólną w postaci oszczędności kosztów, stwierdzała, że kryteria indywidualne są im nieznane.

Kolejna indagacja dotyczyła zmian w zakresie poczucia stabilności zatrudnienia $w$ firmie po redukcji zatrudnienia.

Pięciu respondentów odpowiedziało, że poczucie stabilności zatrudnienia zmniejszyło się, dwóch, że pozostało bez zmian, a jeden, że zwiększyło się. Jak się okazuje, konsekwencje emocjonalne zwolnień mogą być dotkliwe. „Nagle to, co wydawało się trwałe i stabilne, okazuje się kruche. Pojawia się wewnętrzne rozdarcie - na pierwszym miejscu jest ulga, ale zaraz za nią obawy oraz widmo "trybika w maszynie». Niewiedza, z jakiego powodu pracownik nie został zwolniony, może dodatkowo negatywnie wpływać na motywację. Sytuacja zaczyna wykraczać ponad normalne strategie radzenia sobie ze zmianą czy stresem" (http://praca.wp.pl/title,Syndrom-ocalonego-czyli-zycie-w-leku 2014). Nic więc dziwnego, że poczucie stabilności ucierpiało. W tym kontekście, jedna deklaracja o zwiększeniu poczucia stabilności zatrudnienia wydaje się dość spektakularna. Wyjaśnia to analiza odpowiedzi na wszystkie pytania ankietowe - okazuje się bowiem, że jest to również jedyna osoba twierdząca, że redukcja zatrudnienia zwiększyła jej poziom lojalności i zaangażowania. Fakt, że osoba ta nie została objęta redukcją zatrudnienia, 
został przez nią zinterpretowany jako wyraz uznania i respektu dla jej pracy i osiągnięć.

Kolejne pytanie dotyczyło percepcji sprawiedliwości i uczciwości w zakresie redukcji zatrudnienia.

Rozkład odpowiedzi w tym przypadku był identyczny jak w sytuacji pytania drugiego. Czterech respondentów uważało, że decyzje o zwolnieniach były sprawiedliwe i uzasadnione, a sąd pozostałych czterech był odwrotny.

Związek dwóch wskazanych powyżej pytań i odpowiedzi jest raczej oczywisty. Te osoby, które potraktowały przyczynę wdrożenia redukcji zatrudnienia (przyczyna ekonomiczna) jako tożsamą z indywidualnymi kryteriami zwolnień, prawdopodobnie uznali, że cała operacja była uczciwa i sprawiedliwa, natomiast ci, którzy traktowali te dwie kategorie rozdzielnie, nie znając personalnych kryteriów zwolnień, ocenili proces redukcji zatrudnienia jako niesprawiedliwy i nieuczciwy. Ogólne uzasadnienie operacji zwolnień było dla nich niewystarczające.

Kolejne pytanie dotyczyło odczuć respondentów w zakresie poziomu stresu związanego z redukcją zatrudnienia. Pięciu respondentów oceniło poziom stresu jako wysoki a trzech jako średni. Wynika stąd, że sytuacja ta, diagnozowana przecież dzień po zwolnieniach, naraża na większy stres tych, którzy pozostali, niż tych, którzy odeszli. Ci, którzy otrzymali wypowiedzenia, jak wynika z krótkich wywiadów z tymi osobami, owszem, doświadczyli silnego stresu, ale miał on charakter jednorazowy i krótkotrwały - później emocje opadły. Natomiast w przypadku tych, których oszczędziła gilotyna cięć, mieliśmy do czynienia ze stresem ukrytym, nierozładowanym i długotrwałym - w rezultacie bardzo dotkliwym i wciąż doświadczanym.

Kolejne pytanie dotyczyło obaw związanych z perspektywą zwiększonego obciążenia pracą na skutek zmniejszenia liczebności personelu.
Siedmiu respondentów wyraziło takie obawy, natomiast jedna osoba nie miała takich obaw.

„Znaczna część trudności przeżywanych przez pozostających w firmie pracowników ma charakter emocjonalny. Związane są one z faktem bycia bezsilnym świadkiem porażki zawodowej współpracowników oraz obaw o własną przyszłość w firmie. Występują także trudności wynikające z nowego sposobu funkcjonowania firmy, oznaczającego niejednokrotnie konieczność wykonywania przez "ocalałych» obowiązków, które do tej pory realizowane były $w$ większym zespole. Zmiany zachodzące w przedsiębiorstwie pociągają też często za sobą konieczność nabycia przez pracownika wielu umiejętności związanych z objęciem nowego stanowiska lub rozszerzeniem zakresu obowiązków na stanowisku dotychczasowym" (Sidor-Rządkowska 2013, www.ipiss. com.pl). Nic więc dziwnego, że dominują uczucia niepewności i obaw związanych z przewidywanym zwiększeniem obciążeń.

Następne pytanie dotyczyło wpływu redukcji zatrudnienia na pojawienie się lęku przed jakąkolwiek zmianą.

Pięciu respondentów stwierdziło, że redukcja zatrudnienia spowodowała wśród nich obawę przed następnymi zmianami, jeden nie miał takich obaw, a dwóch nie dostrzegało związku między zwolnieniami i kolejnymi zmianami.

W związku z tym, że redukcja zatrudnienia była zmianą zaskakującą, stresującą i burzącą poczucie stabilności, wśród pracowników pojawiły się obawy, że kolejne zmiany również odczują w nieprzyjemny sposób. Stąd naturalny opór przeciw zmianom został spotęgowany szczególną dotkliwością zmiany pierwotnej. Poza tym, brak wpływu na kierunek i intensywność wdrażanych modyfikacji spowodował niższy stopień identyfikacji pracowników ze zmianami wprowadzanymi 
w firmie - gdy brakuje partycypacji w determinowaniu zmian, obawy przed następnymi zmianami rosną. Następne pytanie dotyczyło określenia wpływu redukcji zatrudnienia na poziom lojalności i zaangażowania.

Trzech respondentów stwierdziło, że wpływ zwolnień ma charakter negatywny, czterech określiło ten wpływ jako neutralny, a jeden jako pozytywny (ta ostatnia to osoba wspomniana wcześniej, która pozostawienie jej wśród nadal zatrudnionych potraktowała jako wyróżnienie).

Taki brak zdecydowania można prawdopodobnie złożyć na karb okoliczności zadawania pytań. W tak emocjonalnych warunkach, dzień po zwolnieniach, łatwiej jest skupić się na skutkach, które dotykają nas bezpośrednio, tu i teraz. Konsekwencje bardziej długookresowe, będące odzewem na doznaną krzywdę emocjonalną i lokujące się po stronie pracodawcy, muszą przejść okres refleksji, aby postawa ich dotycząca była bardziej zdecydowana.

Kolejna indagacja dotyczyła określenia wpływu redukcji zatrudnienia na motywację do pracy i na chęć robienia więcej niż wymagane minimum.

W tym przypadku, podobnie jak w poprzednim, odpowiedzi były zróżnicowane. Dwóch respondentów określiło ten wpływ jako negatywny, dwóch jako pozytywny, a czterech jako neutralny. Uzasadnienie takiego rozkładu odpowiedzi jest podobne jak poprzednio. Trudno w chwili nasilonych emocji myśleć rozsądnie i racjonalnie prognozować swoje zachowania w przyszłości - stąd wynika przewaga odpowiedzi neutralnych. Te bardziej zdecydowane odpowiedzi to prawdopodobnie odpowiedzi odruchowe, będące wynikiem kotłujących się myśli i uczuć.

Kolejne pytanie dotyczyło określenia poczucia doinformowania na temat tego, co się dzieje $w$ firmie.

Pięciu respondentów miało poczucie niedoinformowania, a trzech czuło się doinformowanych.
W związku z tym, że badana firma jest mała, a zatrudnienie bardzo często krzyżowe, siłą rzeczy przepływ informacji jest ułatwiony. Nic zatem dziwnego, że do części pracowników dotarły informacje o przygotowywanej redukcji zatrudnienia. Jednak większość czuła się niedoinformowana i zaskoczona zaistniałą zmianą. Wynikało to $w$ części z braku uczestnictwa w przygotowywaniu zmiany, a w części z błędów kierownictwa w zakresie komunikacji z pracownikami, a nawet ze świadomego limitowania dostępu do informacji na ten temat.

Ostatnie pytanie dotyczyło określenia stopnia zaufania, jakim po redukcji zatrudnienia obdarzane było kierownictwo firmy.

Ponownie odpowiedzi oscylowały wokół stanów neutralnych. Pięciu respondentów stwierdziło, że nastąpiło ograniczenie zaufania, a trzech, że zaufanie pozostało bez zmian. Nikt nie wybrał opcji skrajnych, tj. utraty zaufania i wzrostu zaufania.

Jak poporzednio - odpowiedzi wymagają przemyśleń, a więc czasu na refleksję. Mimo wszystko wydaje się, że zaufanie zostało jednak nadwyrężone. Nikt nie lubi być zaskakiwany. Ludzie pragną przewidywalności i otwartości. Nieufność jest wynikiem braku świadomości, czego należy oczekiwać. Z drugiej strony, brak zaufania wywodzi się $w$ takim samym stopniu z tego, o czym ludzie nie wiedzą, jak i z tego, o czym wiedzą. Otwartość prowadzi więc do zaufania i wiarygodności. Należy więc informować swoich ludzi, doprowadzać do całkowitej jasności kryteriów decyzyjnych, wyjaśniać logikę swoich decyzji, szczerze przedstawiać problemy, w pełni ujawniać istotne informacje (Robbins 2004: 275). Gdy brakuje przewidywalności i otwartości, cierpi na tym zaufanie.

Biorąc pod uwagę, że część odpowiedzi była skażona zbytnią emocjonalnością wypowiedzi i niemożnością precyzyjnego wyrażenia myśli, autor 
postanowił przeprowadzić drugą turę badań po upływie dwóch miesięcy, obejmując nimi tą samą grupę respondentów. Mając nadzieję na większe zdecydowanie w wyrażaniu opinii po przemyśleniach i refleksji nad zmienioną sytuacją, w której znaleźli się ci, którzy utrzymali zatrudnienie, zadano ponownie te same pytania ankietowe.

Najistotniejsze zmiany w wynikach były następujące:

- zniknął optymista, który sądził, że fakt pozostawienia go wśród zatrudnionych jest wynikiem docenienia jego kwalifikacji i wyjątkowości (prawdopodobnie zmienił zdanie, weryfikując na niekorzyść własną samoocenę i ocenę przełożonych);

- zwiększyła się (o jedną osobę) liczba respondentów, którzy uważali, że decyzje o zwolnieniach były niesprawiedliwe i nieuzasadnione;

- wszyscy respondenci zaczęli wyrażać obawy związane z perspektywą zwiększonego obciążenia pracą na skutek zmniejszenia liczebności personelu. W części było to efektem już doświadczanego przez nich rzeczywistego zwiększenia zakresu obowiązków i nikłych jeszcze doświadczeń z nowym, dopiero wdrażanym, systemem motywacyjnym;

- zwiększyła się (o jedną osobę) liczba respondentów, którzy stwierdzili, że redukcja zatrudnienia spowodowała wśród nich obawę przed następnymi zmianami;

- $z$ trzech do pięciu zwiększyła się liczba respondentów, którzy stwierdzili, że zwolnienia mają negatywny wpływ na poziom lojalności i zaangażowania;

- w przypadku wpływu redukcji zatrudnienia na motywację do pracy i chęć robienia więcej niż wymagane minimum zmiana $w$ rozkładzie odpowiedzi miała charakter spektakularny - liczba tych, którzy określali ten wpływ jako pozytywny, z dwóch osób zwiększyła się do pięciu. Zmianę tą przypisuje się wdrożeniu przez kierownictwo firmy, natychmiast po redukcji zatrudnienia, atrakcyjnego systemu motywacyjnego, który wybitnie promuje pracę $\mathrm{w}$ nadgodzinach. Reguły tego systemu pozytywnie wpłynęły na motywację. Czas pokaże, na ile te zmiany będą miały trwały charakter;

- z pięciu do siedmiu zwiększyła się liczba respondentów, którzy stwierdzili, że zwolnienia spowodowały u nich ograniczenie zaufania do kierownictwa firmy.

Jak można zauważyć, odpowiedzi z pierwszej tury pytań zostały wyraźnie zweryfikowane. Te z drugiej tury, po refleksji i pewnych doświadczeniach funkcjonowania $w$ okrojonym składzie, stały się bardziej zdecydowane i radykalne. Błędy kierownictwa stały się wyraźniej dostrzegalne, uczucie straty bardziej dojmujące, a konsekwencje zmiany przeżywane głębiej i oceniane bardziej krytycznie.

\section{Zakończenie}

Redukcja zatrudnienia pociąga za sobą konieczność przystosowania się do nowej sytuacji, również i tych, którzy pozostali w organizacji. Jest to istotne, szczególnie wtedy, gdy ograniczenia w zatrudnieniu miały duży zasięg. Mimo że derekrutacja personelu jest ukierunkowana na podniesienie efektywności organizacji i tworzy nowe możliwości na przyszłość, jest jednak zabiegiem bolesnym i może pociągać za sobą również niezamierzone skutki ujemne. Na podstawie licznych badań stwierdzono, że tego typu sytuacje prowadzą do powstania swego rodzaju choroby u osób pozostających w organizacji, która objawia się takimi symptomami jak strach, niepewność, brak poczucia bezpieczeństwa, frustracja, urazy, gniew, depresja, co z kolei przekłada się na utratę motywacji, zaangażowania i zaufania, bez których 
osiągnięcie sukcesu przez organizację jest niemożliwe.

Zaprezentowane studium przypadku potwierdza te tendencje, przede wszystkim w zakresie emocji, których doznają ci, którzy „ocaleli”. Pierwsza konstatacja po operacji redukcji związana z uchronieniem się przed zwolnieniem jest emocją pozytywną - jest to ulga połączona z pewną satysfakcją, być może niezbyt intensywna, ale łagodząca oceny negatywne. Gdy po pewnym czasie te pozytywne uczucia zanikają, pojawiają się emocje ewidentnie negatywne związane z lękiem przed zmianą, z obawą przed nadmiernym obciążeniem dodatkową pracą, z utratą poczucia stabilności zatrudnienia, a więc również ze zwątpieniem w sens angażowania się czy okazywania lojalności - $w$ rezultacie mamy do czynienia z huśtawką emocji. Więcej światła na ten stan emocjonalny rzuca teoria procesów przeciwstawnych sformułowana przez R. Solomona. Zakłada ona, że zakończenie jednej emocji automatycznie włącza emocję w stosunku do niej przeciwstawną. Jeśli zatem ktoś doświadczył emocji pozytywnej, wygaśnięcie jej przyczyn powoduje pojawienie się emocji negatywnej (Witkowski 2006: 115). Zauważono jednocześnie, że uczucia tych osób krystalizują się dopiero po pewnym czasie, stają się bardziej wyraziste i jednoznaczne po procesie racjonalizacji i refleksji. Niestety, potwierdza się również stereotyp zachowań kierownictwa firmy, które lekceważy przygotowanie do wprowadzenia tak wrażliwych zmian, nie wciąga pracowników $w$ ich projektowanie i nie dostrzega traumy, którą przeżywają ci, którzy uniknęli redukcji. Autor wyraża nadzieję, że niniejszy artykuł da asumpt do rewizji zachowań kierownictwa, $w$ trakcie kolejnych redukcji zatrudnienia, w kierunku uwzględnienia potrzeb nie tylko zwalnianych, ale również i tych, którzy pozostali w firmie.

\section{Bibliografia}

Downs A. (2007), Jak ograniczyć zatrudnienie w dobrym stylu?, [w:] Biznes. Zarzqdzanie zasobami ludzkimi, t. 5, Warszawa, Wydawnictwo Naukowe PWN.

Harrisom S. (2008), Przyzwoitość $w$ zarzqdzaniu. Jak małe gesty budujq wielkie firmy, Kraków, Oficyna Wolters Kluwer.

Juchnowicz M. (2010), Zarzqdzanie przez zaangażowanie, Warszawa, PWE.

Pocztowski A. (2008), Zarzq̨dzanie zasobami ludzkimi, Warszawa, PWE.

Robbins S.P. (2003), Prawdy o kierowaniu ludźmi... i tylko prawdy, Warszawa, PWE.
Robbins S.P. (2004), Zachowania w organizacji, Warszawa, PWE.

Sidor-Rządkowska M., Trudna sztuka rozstań, http://www.ipiss.com.pl (24.05.2013).

Sidor-Rządkowska M. (2010), Zwolnienia pracowników a polityka personalna firmy, Warszawa, Oficyna Wolters Kluwer business.

Sowa B., Ocaleni pracownicy identyfikujg się z losem zwolnionych, http://www.centrumrekrutacyjne.pl (24.05.2014).

Sternberg E. (1998), Czysty biznes. Etyka biznesu w działaniu, Warszawa, Wydawnictwo Naukowe PWN. 
Syndrom ocalonego, czyli życie w lęku, http://praca.wp.pl/title,Syndrom-ocalonego-czyli-zycie-w-leku, wid,16462003, wiadomosc.html (24.05.2014).
Sztompka P. (2007), Zaufanie. Fundament społeczeństwa, Kraków, Wydawnictwo Znak.

Witkowski T. (2006), Psychomanipulacje, Taszów, Biblioteka Moderatora.

\title{
Psychosocial effects of employment reduction and counteraction on the example of the investment company
}

\begin{abstract}
This paper presents the issue of psychosocial effects of de-recruitment with reference to those employees who avoid employment reduction. In that context the paper formulated its aim being a recognition of the effects mentioned above and ways of protecting against destructive effects of de-recruitment. The issue portrayed in the paper is supported by case study analysis describing an investment company, and results of questionnaire empirical research. The results of this research indicate that reduction of employment in the company in question was improperly performed. Among the employees who avoided it, it evoked a feelings of instability, increase of stress and decrease of loyalty and trust, as well as fear of additional efforts in the job. To add, the decision on employment reduction has been evaluated as unfair and unnecessary. Such feelings increased in time. The author also presents suggestions of constructive behavior and projects oriented towards eliminating mistakes and alleviating consequences of such de-recruitment.
\end{abstract}

Keywords: reduction of the employment, results of the reduction, disease of survival of reduction 